\title{
Hongiella marincola sp. nov., isolated from sea water of the East Sea in Korea
} Correspondence
Jung-Hoon Yoon
jhyoon@kribb.re.kr
The genus Hongiella was proposed by Yi \& Chun (2004) with three species, Hongiella mannitolivorans, Hongiella halophila and Hongiella ornithinivorans. However, $H$. halophila has been transferred to the genus Algoriphagus as Algoriphagus halophilus (Nedashkovskaya et al., 2004). In this study, we describe two Gram-negative, slightly halophilic, rod-shaped strains, SW-2 ${ }^{\mathrm{T}}$ and $\mathrm{SW}-26$, that were isolated from sea water from Hwajinpo Beach of the East Sea in Korea. As a result of 16S rRNA gene sequence comparison, these organisms were considered to be related phylogenetically to the Cytophaga-FlavobacteriumBacteroides group and, in particular, to the genus Hongiella. Accordingly, the aim of the present work was to determine the exact taxonomic positions of strains SW-2 ${ }^{\mathrm{T}}$ and $\mathrm{SW}-26$ by using a combination of phenotypic properties, detailed phylogenetic analysis based on 16S rRNA gene sequences and genomic relatedness.

Strains SW-2 ${ }^{\mathrm{T}}$ and SW-26 were isolated by the dilutionplating technique on marine agar 2216 (MA; Difco). Cell

The GenBank/EMBL/DDBJ accession numbers for the 16S rRNA gene sequences of strains SW- $2^{\top}$ and SW-26 and the newly determined $16 \mathrm{~S}$ rRNA gene sequence of Cyclobacterium marinum DMS $745^{\top}$ are AY533663, AY533664 and AY533665, respectively. mass of strains SW $-2^{\mathrm{T}}$ and SW-26 for isoprenoid quinone analysis and DNA extraction was obtained from cultures in marine broth $2216\left(\mathrm{MB}\right.$; Difco) at $37^{\circ} \mathrm{C}$. For fatty acid methyl ester analysis, cell mass of strains SW- $2^{\mathrm{T}}$ and SW-26 was obtained from agar plates after cultivation for 3 days at $37^{\circ} \mathrm{C}$ on MA. Light microscopy (E600 microscope; Nikon) and transmission electron microscopy were used to examine cell morphology. The presence of flagella was determined by transmission electron microscopy using cells from exponentially growing cultures. Gram reaction was determined by using a bioMérieux Gram Stain kit according to the manufacturer's instructions. Growth under anaerobic conditions was determined after incubation in an anaerobic chamber with anaerobically prepared MA. Growth in the absence of $\mathrm{NaCl}$ was investigated in trypticase soy broth without $\mathrm{NaCl}$. Growth at various $\mathrm{NaCl}$ concentrations was investigated in $\mathrm{MB}$. Growth at various temperatures $\left(4-50^{\circ} \mathrm{C}\right)$ was measured on MA. Catalase and oxidase activities and hydrolysis of casein, starch and Tween 80 were determined as described by Cowan \& Steel (1965). Hydrolysis of gelatin, hypoxanthine, tyrosine and xanthine was investigated on MA plates with the substrate concentrations described previously (Cowan \& Steel, 1965). Hydrolysis of aesculin and nitrate reduction were determined as described by Lanyi (1987), with the modification that artificial sea 
water was used instead of distilled water. Artificial sea water contained the following [(1 distilled water $)^{-1}$ ]: $23.6 \mathrm{~g} \mathrm{NaCl}$, $0.64 \mathrm{~g} \mathrm{KCl}, 4.53 \mathrm{~g} \mathrm{MgCl}_{2} .6 \mathrm{H}_{2} \mathrm{O}, 5.94 \mathrm{~g} \mathrm{MgSO}_{4} .7 \mathrm{H}_{2} \mathrm{O}$ and $1.3 \mathrm{~g} \mathrm{CaCl}_{2} \cdot 2 \mathrm{H}_{2} \mathrm{O}$ (Bruns et al., 2001). $\mathrm{H}_{2} \mathrm{~S}$ production was tested as described by Bruns et al. (2001). Hydrolysis of birchwood xylan (Sigma) was determined on solid medium and in liquid marine salts basal medium (Baumann \& Baumann, 1981) that contained $0 \cdot 5 \%(\mathrm{w} / \mathrm{v})$ xylan as the sole carbon source. The API ZYM system (bioMérieux) was used to determine the activity of some enzymes. Acid production from carbohydrates was determined as described by Leifson (1963). Utilization of substrates as sole carbon and energy sources was tested according to the method of Baumann \& Baumann (1981), using supplementation with $2 \%(\mathrm{v} / \mathrm{v})$ Hutner's mineral base (Cohen-Bazire et al., 1957) and $1 \%$ $(\mathrm{v} / \mathrm{v})$ vitamin solution (Staley, 1968). For in vivo pigment absorption-spectrum analysis, cultures were washed twice by centrifugation using a MOPS buffer (MOPS- $\mathrm{NaOH}$, $\left.0.01 \mathrm{M} ; \mathrm{KCl}, 0.1 \mathrm{M} ; \mathrm{MgCl}_{2}, 0.001 \mathrm{M} ; \mathrm{pH} 7 \cdot 5\right)$ and disrupted by sonication with a Branson Sonifier 450. After removal of cell debris, the absorption spectrum of the supernatant was examined on a Beckman Coulter DU800 spectrophotometer.

Chromosomal DNA was isolated and purified according to the method described previously (Yoon et al., 1996), except that ribonuclease $\mathrm{T}_{1}$ was used together with ribonuclease $\mathrm{A}$. Isoprenoid quinones were extracted and analysed as described by Komagata \& Suzuki (1987) using reverse-phase HPLC. For quantitative analysis of cellular fatty acid compositions, a loop of cell mass was harvested and fatty acid methyl esters were extracted and prepared according to the standard protocol of the MIDI/Hewlett Packard Microbial Identification system (Sasser, 1990). The DNA G+C content was determined by the method of Tamaoka \& Komagata (1984), with the modification that DNA was hydrolysed and the resultant nucleotides were analysed by reverse-phase HPLC.
The 16S rRNA gene was amplified by PCR using two universal primers as described previously (Yoon et al., 1998). Sequencing of the amplified 16S rRNA gene and phylogenetic analysis were performed as described previously (Yoon et al., 2003). DNA-DNA hybridization was performed fluorometrically by the method of Ezaki et al. (1989), using photobiotin-labelled DNA probes and microdilution wells. Hybridization was performed with five replications for each sample. The highest and lowest values obtained in each sample were excluded and the remaining three values were used to calculate similarity values. The DNA relatedness values quoted are the means of these three values.

The $16 \mathrm{~S}$ rRNA gene sequences of strains SW $-2^{\mathrm{T}}$ and SW-26 determined in this study each comprised $1476 \mathrm{nt}$, representing approximately $96 \%$ of the Escherichia coli $16 \mathrm{~S}$ rRNA gene sequence. The $16 \mathrm{~S}$ rRNA gene sequences of strains SW$2^{\mathrm{T}}$ and SW-26 were similar ( $99 \cdot 9 \%$ similarity, with only two nucleotide differences). The neighbour-joining tree based on $16 \mathrm{~S}$ rRNA gene sequences showed that strains SW $-2^{\mathrm{T}}$ and SW-26 formed a coherent cluster with Hongiella species (Fig. 1). Strains SW- $2^{\mathrm{T}}$ and SW-26 exhibited $16 \mathrm{~S}$ rRNA gene sequence similarity levels of $94 \cdot 2$ and $96 \cdot 6 \%$, respectively, to the type strains of $H$. mannitolivorans and $H$. ornithinivorans. Sequence similarities to all other species included in the phylogenetic analysis were below $94.9 \%$ (Fig. 1 ).

Morphological, physiological and biochemical characteristics are shown in Table 1 or are given in the species description (see below). Strains SW-2 ${ }^{\mathrm{T}}$ and $\mathrm{SW}-26$ did not grow in the presence of 8 and $9 \%(\mathrm{w} / \mathrm{v}) \mathrm{NaCl}$, respectively. Strain $\mathrm{SW}-2^{\mathrm{T}}$ produced acid from D-fructose, but strain SW-26 did not. Strains SW-2 ${ }^{\mathrm{T}}$ and SW-26 had MK-7 as the predominant isoprenoid quinone. Members of the genus Hongiella were also observed to have MK-7 as the predominant isoprenoid quinone (Yi \& Chun, 2004). Strains $\mathrm{SW}-2^{\mathrm{T}}$ and SW-26 had cellular fatty acid profiles that

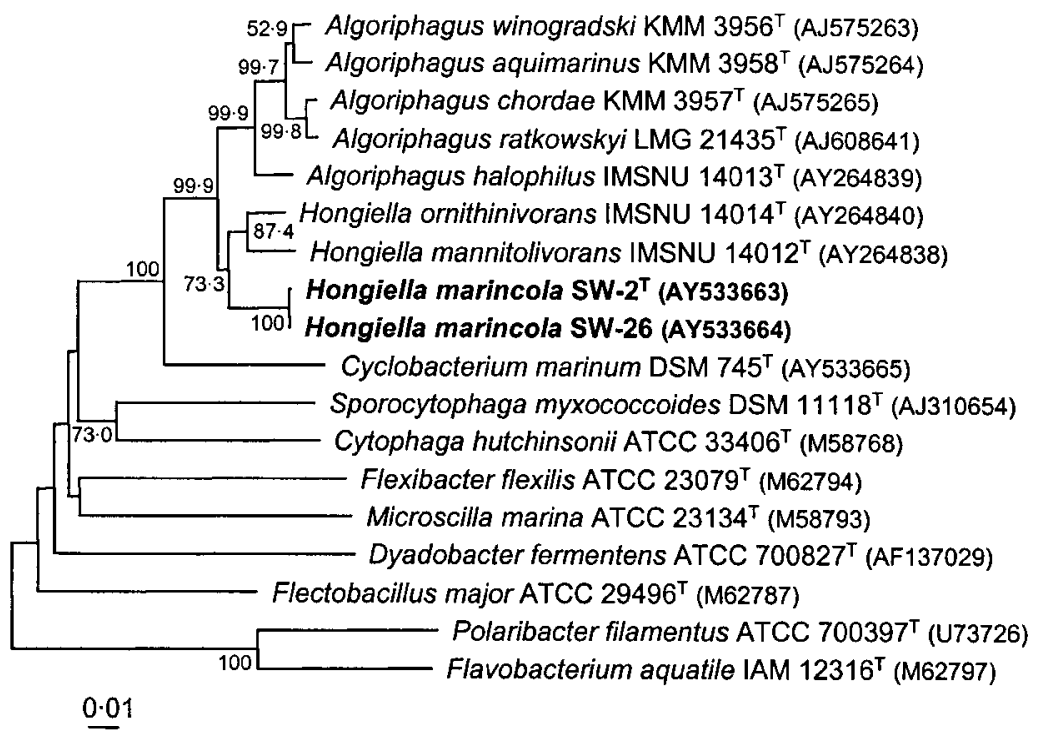

Fig. 1. Neighbour-joining tree based on 16S rRNA gene sequences, showing the phylogenetic positions of strains $S W-2^{T}$ and SW-26 and representatives of some other related taxa. Bootstrap values (1000 replications) of $50 \%$ or greater are shown as percentages at each node. Bar, 0.01 substitutions per nucleotide position. 
Table 1. Differential phenotypic characteristics of $H$. marincola, $H$. mannitolivorans and $H$. ornithinivorans

Species: 1, H. marincola; 2, H. mannitolivorans; 3, H. ornithinivorans. + , Positive; -, negative; $\mathrm{W}$, weakly positive; $\mathrm{V}$, variable reaction. All species are Gram-negative rods with round ends and are non-motile. All of the species test positive for the following: oxidase, catalase, amylase, hydrolysis of aesculin, alkaline phosphatase, leucine arylamidase, acid phosphatase, naphthol-AS-BI-phosphohydrolase, valine arylamidase, trypsin, $\alpha$-chymotrypsin, $N$-acetyl- $\beta$-glucosaminidase and utilization of D-cellobiose, D-glucose, D-mannose, D-raffinose, D-trehalose, D-xylose, lactose and sucrose. All of the species test negative for the following: spore formation, hydrolysis of agar and urea, $\mathrm{H}_{2} \mathrm{~S}$ production, lipase (C14), $\alpha$-mannosidase, $\alpha$-fucosidase, $\beta$-glucuronidase and utilization of acetate, benzoate, citrate, Dsorbitol, D-galactose and L-arabinose.

\begin{tabular}{|c|c|c|c|}
\hline Characteristic & 1 & $2^{*}$ & $3^{*}$ \\
\hline Pigment absorption max. (nm) & 486 & 480 & 480 \\
\hline Nitrate reduction to nitrite & $\mathrm{V}(-) \dagger$ & + & - \\
\hline Gelatinase & - & + & $\mathrm{W}$ \\
\hline Tweenase & + & - & + \\
\hline Hydrolysis of casein & + & - & - \\
\hline \multicolumn{4}{|l|}{ Utilization of: } \\
\hline D-Fructose & + & - & + \\
\hline D-Mannitol & - & + & - \\
\hline Succinate & $\mathrm{V}(+) \dagger$ & - & - \\
\hline \multicolumn{4}{|c|}{ Enzyme activity (with API ZYM system): } \\
\hline Esterase (C4) & + & - & - \\
\hline Esterase lipase (C8) & + & - & - \\
\hline Cystine arylamidase & + & - & - \\
\hline$\alpha$-Galactosidase & - & + & + \\
\hline$\beta$-Galactosidase & + & + & $\mathrm{W}$ \\
\hline$\alpha$-Glucosidase & + & - & + \\
\hline$\beta$-Glucosidase & $\mathrm{W}$ & - & + \\
\hline Growth with $0 \% \mathrm{NaCl}$ & - & + & + \\
\hline Growth at $45^{\circ} \mathrm{C}$ & + & - & + \\
\hline DNA $G+C$ content $(\mathrm{mol} \%)$ & 43 & 42 & 38 \\
\hline
\end{tabular}

${ }^{\star}$ Data from Yi \& Chun (2004).

$\dagger$ The reaction of the type strain, SW $-2^{\mathrm{T}}$, is indicated in parentheses.

contained large amounts of branched, unsaturated and hydroxy fatty acids (Table 2). These fatty acid profiles were similar to those of the type strains of two Hongiella species described previously (Table 2). Strains SW- $2^{\mathrm{T}}$ and SW-26 contained iso- $\mathrm{C}_{15: 0}$ as the major fatty acid (Table 2 ). The DNA $\mathrm{G}+\mathrm{C}$ contents of strains $\mathrm{SW}-2^{\mathrm{T}}$ and $\mathrm{SW}-26$ were the same, i.e. $43 \mathrm{~mol} \%$. Strains $\mathrm{SW}-2^{\mathrm{T}}$ and SW-26 exhibited a mean DNA-DNA relatedness value of $87 \%$ when their DNA was used individually as a labelled DNA probe. This value indicates that strains $\mathrm{SW}-2^{\mathrm{T}}$ and $\mathrm{SW}-26$ are members of the same genomic species (Wayne et al., 1987).

$16 \mathrm{~S}$ rRNA gene sequence analysis indicated that strains SW $-2^{\mathrm{T}}$ and SW-26 have the closest phylogenetic affiliations to the genus Hongiella (Fig. 1). Chemotaxonomic analysis
Table 2. Cellular fatty acid composition (\%) of $H$. marincola strains $\mathrm{SW}-2^{\top}$ and $\mathrm{SW}-26, H$. mannitolivorans strain $\mathrm{JC} 2050^{\top}$ and $H$. ornithinivorans strain $\mathrm{JC} 2052^{\top}$

Strains: 1, H. marincola SW-2 ${ }^{\mathrm{T}}$; 2, H. marincola SW-26; 3, H. mannitolivorans $\mathrm{JC}^{2050^{\mathrm{T}}}$ (data from Yi \& Chun, 2004); 4, H. ornithinivorans $\mathrm{JC}^{2} 252^{\mathrm{T}}$ (data from Yi \& Chun, 2004). Fatty acids representing $\geqslant 1 \%$ of the total fatty acid content of at least one of the strains are shown.

\begin{tabular}{|c|c|c|c|c|}
\hline Fatty acid & 1 & 2 & 3 & 4 \\
\hline \multicolumn{5}{|c|}{ Straight-chain fatty acid: } \\
\hline $\mathrm{C}_{15: 0}$ & $4 \cdot 4$ & $2 \cdot 4$ & $1 \cdot 7$ & $0 \cdot 7$ \\
\hline \multicolumn{5}{|c|}{ Branched fatty acids: } \\
\hline anteiso- $\mathrm{C}_{11: 0}$ & 0 & 0 & $1 \cdot 7$ & 0 \\
\hline iso- $\mathrm{C}_{14: 0}$ & $1 \cdot 4$ & $1 \cdot 1$ & $1 \cdot 2$ & $0 \cdot 5$ \\
\hline iso- $\mathrm{C}_{15: 0}$ & $34 \cdot 3$ & $35 \cdot 6$ & $28 \cdot 7$ & $29 \cdot 2$ \\
\hline iso- $\mathrm{C}_{15: 1} \mathrm{G}$ & 0 & 0 & $1 \cdot 0$ & $1 \cdot 1$ \\
\hline anteiso- $\mathrm{C}_{15: 0}$ & $4 \cdot 9$ & $4 \cdot 3$ & $4 \cdot 6$ & $4 \cdot 9$ \\
\hline iso- $\mathrm{C}_{16: 0}$ & $6 \cdot 7$ & $5 \cdot 1$ & $3 \cdot 7$ & $3 \cdot 6$ \\
\hline iso- $\mathrm{C}_{16: 0} \mathrm{G}$ & 0 & 0 & 0 & $1 \cdot 9$ \\
\hline iso- $\mathrm{C}_{16: 1} \mathrm{H}$ & $1 \cdot 8$ & $1 \cdot 4$ & $2 \cdot 8$ & $1 \cdot 6$ \\
\hline iso- $\mathrm{C}_{17: 1} \omega 9 c$ & $2 \cdot 4$ & $3 \cdot 6$ & $5 \cdot 6$ & $7 \cdot 8$ \\
\hline \multicolumn{5}{|c|}{ Unsaturated fatty acids: } \\
\hline $\mathrm{C}_{15: 1} \omega 6 c$ & $2 \cdot 0$ & $1 \cdot 3$ & $2 \cdot 5$ & $1 \cdot 1$ \\
\hline $\mathrm{C}_{16: 1} \omega 5 c$ & 0 & $2 \cdot 6$ & $1 \cdot 3$ & $1 \cdot 7$ \\
\hline $\mathrm{C}_{17: 1} \omega 6 c$ & $3 \cdot 6$ & $2 \cdot 7$ & $3 \cdot 1$ & $2 \cdot 6$ \\
\hline \multicolumn{5}{|l|}{ Hydroxy fatty acids: } \\
\hline iso- $\mathrm{C}_{15: 0} 3-\mathrm{OH}$ & $3 \cdot 4$ & $3 \cdot 3$ & $3 \cdot 6$ & $3 \cdot 4$ \\
\hline iso- $\mathrm{C}_{16: 0} 3-\mathrm{OH}$ & $3 \cdot 6$ & $1 \cdot 9$ & $4 \cdot 0$ & $2 \cdot 3$ \\
\hline $\mathrm{C}_{16: 0} 3-\mathrm{OH}$ & $0 \cdot 6$ & 0 & $0 \cdot 6$ & $0 \cdot 5$ \\
\hline $\mathrm{C}_{17: 0} 2-\mathrm{OH}$ & $0 \cdot 8$ & $0 \cdot 6$ & $0 \cdot 7$ & $1 \cdot 6$ \\
\hline iso- $\mathrm{C}_{17: 0} 3-\mathrm{OH}$ & $7 \cdot 8$ & $8 \cdot 8$ & $7 \cdot 9$ & $11 \cdot 1$ \\
\hline \multicolumn{5}{|l|}{ Summed features ${ }^{\star}$ : } \\
\hline 3 & $13 \cdot 7$ & $15 \cdot 5$ & $13 \cdot 7$ & $14 \cdot 0$ \\
\hline 4 & $3 \cdot 1$ & $3 \cdot 3$ & $4 \cdot 8$ & $4 \cdot 9$ \\
\hline
\end{tabular}

* Summed features represent groups of two or three fatty acids that could not be separated by GLC with the MIDI system. Summed feature 3 contained one or more of $\mathrm{C}_{16: 1} \omega 7 c$ and/or iso- $\mathrm{C}_{15: 0} 2-\mathrm{OH}$. Summed feature 4 contained one or more of an unknown fatty acid of iso- $\mathrm{C}_{17: 1} \mathrm{I}$ and/or anteiso- $\mathrm{C}_{17: 1} \mathrm{~B}$.

confirms the result of monothetic classification based on $16 \mathrm{~S}$ rRNA gene sequence analysis. The predominant isoprenoid quinone and cellular fatty acid profile of strains SW $-2^{\mathrm{T}}$ and SW-26 were most similar to those of Hongiella species, although the genus Algoriphagus, its phylogenetic neighbour, has a fatty acid profile similar to that of the genus Hongiella (Yi \& Chun, 2004; Nedashkovskaya et al., 2004). Accordingly, in view of these combined chemotaxonomic and phylogenetic analyses, strains SW $-2^{\mathrm{T}}$ and SW-26 are considered as members of the genus Hongiella. Strains SW $-2^{\mathrm{T}}$ and SW-26 are differentiated from the two Hongiella species by some physiological and biochemical characteristics, as shown in Table 1. The levels of 16S rRNA gene sequence similarity warrant the separation of strains $\mathrm{SW}-2^{\mathrm{T}}$ 
and SW-26 from the two Hongiella species described previously (Stackebrandt \& Goebel, 1994). Therefore, on the basis of phenotypic and chemotaxonomic data and phylogenetic distinctiveness, strains $\mathrm{SW}-2^{\mathrm{T}}$ and $\mathrm{SW}-26$ should be classified within the genus Hongiella as a novel species, for which the name Hongiella marincola sp. nov. is proposed.

\section{Description of Hongiella marincola sp. nov.}

Hongiella marincola (ma.rin' co.la. L. gen. n. maris of the sea; L. n. incola inhabitant; N.L. n. marincola inhabitant of the sea).

Cells are rods, $0 \cdot 4-0 \cdot 6 \times 2 \cdot 0-3 \cdot 0 \mu \mathrm{m}$ on MA. Non-motile. Colonies are circular, smooth, low convex, glistening, moderately reddish-orange in colour and $1 \cdot 0-2 \cdot 0 \mathrm{~mm}$ in diameter after 3 days incubation at $37^{\circ} \mathrm{C}$ on MA. Optimal growth temperature is $37^{\circ} \mathrm{C}$. Growth occurs at 10 and $45^{\circ} \mathrm{C}$, but not at $4{ }^{\circ} \mathrm{C}$ or above $46^{\circ} \mathrm{C}$. Optimal pH for growth is between $6 \cdot 5$ and $7 \cdot 5$. Growth is observed at $\mathrm{pH} 5 \cdot 5$, but not at $\mathrm{pH} 5 \cdot 0$. Optimal growth occurs in the presence of $2-3 \%(\mathrm{w} / \mathrm{v}) \mathrm{NaCl}$. No growth occurs in the presence of $>9 \%(\mathrm{w} / \mathrm{v}) \mathrm{NaCl}$. Growth does not occur under anaerobic conditions on MA. Tyrosine is hydrolysed weakly. Hypoxanthine, xanthine and birchwood xylan are not hydrolysed. Acid is produced from D-xylose, melibiose, L-arabinose, D-melezitose, D-glucose, D-galactose, D-mannose, D-cellobiose, lactose, sucrose, maltose, D-trehalose and D-raffinose, but not from D-sorbitol, myo-inositol, D-ribose, D-mannitol, adonitol or L-rhamnose. Acid production from D-fructose is variable (positive for type strain). Formate is not utilized. The predominant isoprenoid quinone is MK-7. The major fatty acids are iso- $\mathrm{C}_{15: 0}$, iso- $\mathrm{C}_{17: 0} 3-\mathrm{OH}$, iso- $\mathrm{C}_{16: 0}$ and $\mathrm{C}_{16: 1} \omega 7 c$ and/or iso- $\mathrm{C}_{15: 0} 2-\mathrm{OH}$. The DNA G + C content is $43 \mathrm{~mol} \%$ (HPLC). Other phenotypic characteristics are given in Table 1.

The type strain, SW $-2^{\mathrm{T}}\left(=\right.$ KCTC $12180^{\mathrm{T}}=$ DSM $\left.16067^{\mathrm{T}}\right)$, was isolated from sea water of the East Sea of Korea. The reference strain is SW-26 (= KCTC 12181 = DSM 16068).

\section{Acknowledgements}

This work was supported by the 21C Frontier programme of Microbial Genomics and Applications (grant MG02-0401-001-1-0-0) from the Ministry of Science and Technology (MOST) of the Republic of Korea and by a grant from KRIBB Research Initiative Programme.

\section{References}

Baumann, P. \& Baumann, L. (1981). The marine Gram-negative eubacteria: genera Photobacterium, Beneckea, Alteromonas, Pseudomonas, and Alcaligenes. In The Prokaryotes. A Handbook on Habitats, Isolation, and Identification of Bacteria, pp. 1302-1331. Edited by M. P. Starr, H. Stolp, H. G. Trüper, A. Balows \& H. G. Schlegel. Berlin: Springer.
Bruns, A., Rohde, M. \& Berthe-Corti, L. (2001). Muricauda ruestringensis gen. nov., sp. nov., a facultatively anaerobic, appendaged bacterium from German North Sea intertidal sediment. Int J Syst Evol Microbiol 51, 1997-2006.

Cohen-Bazire, G., Sistrom, W. R. \& Stanier, R. Y. (1957). Kinetic studies of pigment synthesis by non-sulfur purple bacteria. J Cell Comp Physiol 49, 25-68.

Cowan, S. T. \& Steel, K. J. (1965). Manual for the Identification of Medical Bacteria. London: Cambridge University Press.

Ezaki, T., Hashimoto, Y. \& Yabuuchi, E. (1989). Fluorometric deoxyribonucleic acid-deoxyribonucleic acid hybridization in microdilution wells as an alternative to membrane filter hybridization in which radioisotopes are used to determine genetic relatedness among bacterial strains. Int J Syst Bacteriol 39, 224-229.

Komagata, K. \& Suzuki, K. (1987). Lipid and cell wall analysis in bacterial systematics. Methods Microbiol 19, 161-206.

Lanyi, B. (1987). Classical and rapid identification methods for medically important bacteria. Methods Microbiol 19, 1-67.

Leifson, E. (1963). Determination of carbohydrate metabolism of marine bacteria. J Bacteriol 85, 1183-1184.

Nedashkovskaya, O. I., Vancanneyt, M., Van Trappen, S. \& 7 other authors (2004). Description of Algoriphagus aquimarinus sp. nov., Algoriphagus chordae sp. nov. and Algoriphagus winogradskyi sp. nov., from sea water and algae, transfer of Hongiella halophila Yi and Chun 2004 to the genus Algoriphagus as Algoriphagus halophilus comb. nov. and emended descriptions of the genera Algoriphagus Bowman et al. 2003 and Hongiella Yi and Chun 2004. Int J Syst Evol Microbiol 54, 1757-1764.

Sasser, M. (1990). Identification of Bacteria by Gas Chromatography of Cellular Fatty Acids (technical note no. 101). Newark, DE: MIDI Inc. (http://www.midi-inc.com/media/pdfs/TechNote_101.pdf).

Stackebrandt, E. \& Goebel, B. M. (1994). Taxonomic note: a place for DNA-DNA reassociation and 16S rRNA sequence analysis in the present species definition in bacteriology. Int $J$ Syst Bacteriol 44, 846-849.

Staley, J. T. (1968). Prosthecomicrobium and Ancalomicrobium: new prosthecate freshwater bacteria. J Bacteriol 95, 1921-1942.

Tamaoka, J. \& Komagata, K. (1984). Determination of DNA base composition by reverse-phase high-performance liquid chromatography. FEMS Microbiol Lett 25, 125-128.

Wayne, L. G., Brenner, D. J., Colwell, R. R. \& 9 other authors (1987). International Committee on Systematic Bacteriology. Report of the ad hoc committee on reconciliation of approaches to bacterial systematics. Int J Syst Bacteriol 37, 463-464.

Yi, H. \& Chun, J. (2004). Hongiella mannitolivorans gen. nov., sp. nov., Hongiella halophila sp. nov. and Hongiella ornithinivorans sp. nov., isolated from tidal flat sediment. Int J Syst Evol Microbiol 54, 157-162.

Yoon, J.-H., Kim, H., Kim, S.-B., Kim, H.-J., Kim, W. Y., Lee, S. T., Goodfellow, M. \& Park, Y.-H. (1996). Identification of Saccharomonospora strains by the use of genomic DNA fragments and rRNA gene probes. Int J Syst Bacteriol 46, 502-505.

Yoon, J.-H., Lee, S. T. \& Park, Y.-H. (1998). Inter- and intraspecific phylogenetic analysis of the genus Nocardioides and related taxa based on $16 \mathrm{~S}$ rDNA sequences. Int $J$ Syst Bacteriol 48, 187-194.

Yoon, J.-H., Kim, I.-G., Kang, K. H., Oh, T.-K. \& Park, Y.-H. (2003). Alteromonas marina sp. nov., isolated from sea water of the East Sea in Korea. Int J Syst Evol Microbiol 53, 1625-1630. 